\title{
Article
}

\section{Antioxidant Statues, Growth and Some Physiological Performances of the Gimmizah Male Chickens Supplemented by Dietary Spirulina platensis Under Chronic Heat Stress.}

\author{
Abaza, I. M. ${ }^{1}$; A. A. Abdalla ${ }^{2}$; Amr M. Helal ${ }^{3}$ and Effat.Y.Shreif ${ }^{2}$.
1. Poultry Nutrition, Faculty of Desert and Environmental Agriculture, Matrouh University.
2. Anim. Prod. Res. Inst., Agric. Res. Center, Min. of Agric,
3. Researcher. National Institute of Oceanography and Fishers
}

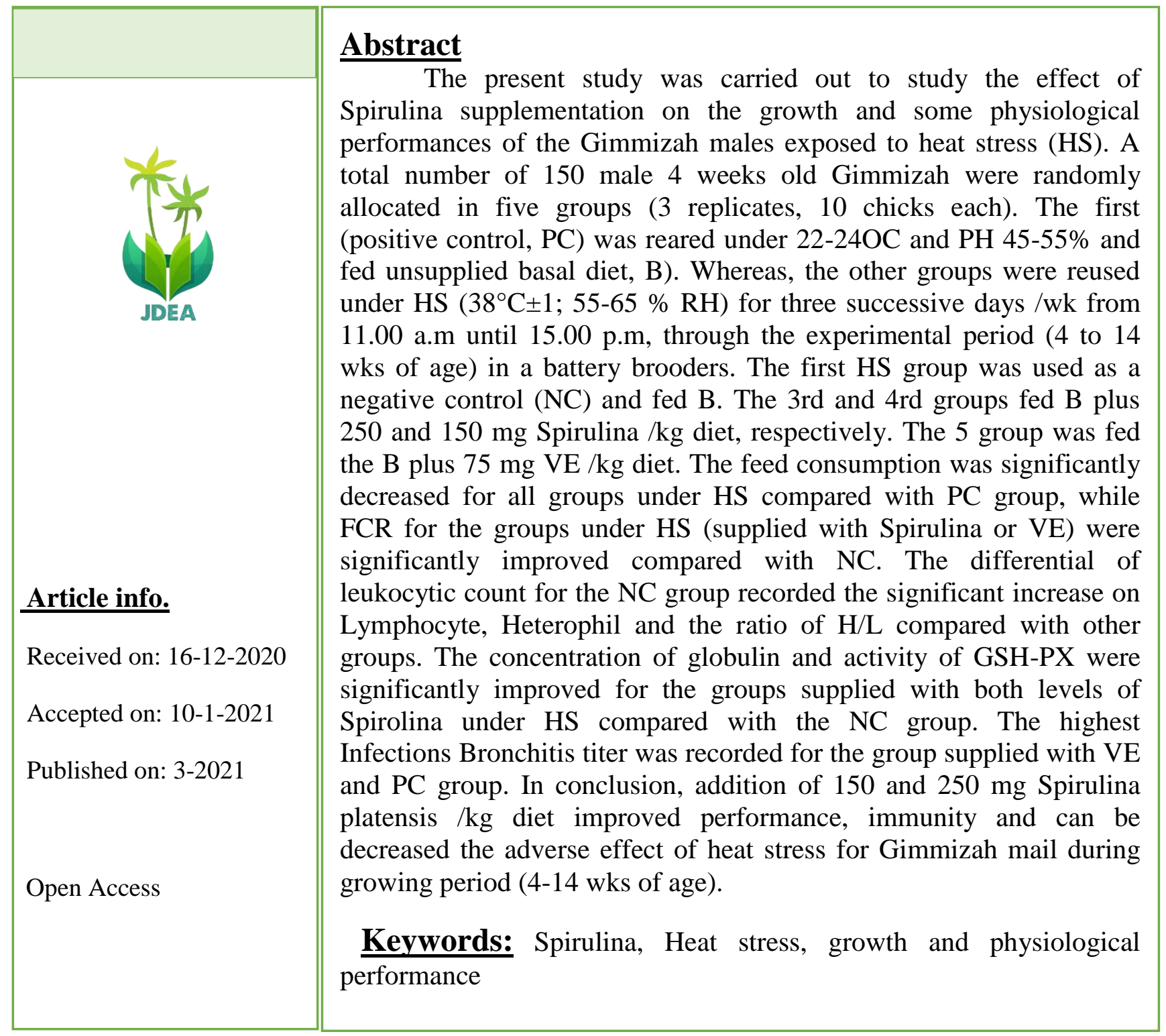

Journal of Desert and Environmental Agriculture, 2021. 


\section{Introduction}

Spirulina is a blue-green microalgae grow in fresh water, it contains substances such as phycobiliproteins (for example phycocyanin (Eriksen, 2008), carotenoids such as $\beta$ carotene and zeaxanthin), high iron and vitamin contents and antioxidants (Maoka, 2011, Hemalatha et al., 2012 and Christaki et al., 2013). These compounds reveal potential biological properties such as antimicrobial, antioxidant, anti-cancer immunostimulating, anti- inflammatory, colorants and hypolipidemic action (AbuTaweel et al., 2016; Hamed et al., 2019; Batista et al., 2013 ; Christaki et al., 2013) and it is generally regarded as safe (GRAS) by the European Food Safety Authority (EFSA) (Chacon-Lee et al., 2010). Anbarasan et al. (2011) indicated that the phytochemical screening of the ethanolic extract of algae. Spirulina platensis shows the presence of alkaloids, flavonoids, glycosides, tannins and phenolic compounds, steroids, and saponins. The naturally essential nutrients and numerous biochemical and physiological content in Spirulina, make it ideal as a natural feed additive in animal and poultry nutrition (Borowttzka, 2013). Also, Mirzaie et al. (2018) reported that Spirulina supplementation in the broiler's diet decreased stress hormones concentration and serum lipid profile meanwhile increased humoral immune response and antioxidants in heat-stressed broilers.

The comfortable temperature for poultry is about 20-25 ${ }^{\circ} \mathrm{C}$ (Daghir, 2008; Tumová and Gous, 2012), and when the ambient temperature becomes higher than $27{ }^{\circ} \mathrm{C}$, the symptoms of heat stress (HS) begins and is readily apparent above $30{ }^{\circ} \mathrm{C}$ (Bollengierlee et al., 1999; Attia et al., 2006). Since, one of the major challenges facing the poultry industry is the higher ambient temperature in the summer months that negatively affects growth performance and physiological traits (Mashaly et al., 2004; Daghir, 2008; Yoshida et al., 2011). Enass et al., (2019) indicated that dietary Spirulina platensis and organic selenium improved productive and reproductive performance, total antioxidant capacity, glutathione peroxidase, superoxide dismutase and immunoglobulins whereas decreased malondialdehyde level in blood, and can decrease the adverse effect of stress on laying hen under heat stress condition. Therefore, the present study was carried out to investigate the effect of Spirulina platensis levels on the growing performance, some physiological and blood biochemical constituents, antioxidant, and immune response traits of the Gimmizah male exposed to chronic heat stress.

\section{Materials and methods}

\subsection{Birds used and grouping:}

A total of 150 male 4 weeks old Gimmizah local strain chicks $\{$ a cross between White Plymouth Rock $\times$ Dokki-4 (Mahmoud et al., 1982) Male chicks were randomly allocated in a completely randomized design considering five treatment groups with three replicates (each contained 10 chicks). All chicks were raised in a battery brooder placed in a temperaturecontrolled room until 14 weeks of age. The positive control group (PC) was fed the basal diet (B, corn-soybean meal diet, Table 1) only without any supplementation and reared in the first sector under normal temperature $\left(22-24^{\mathrm{O}} \mathrm{C}\right)$ and relative humidity (RH) (45-55\%). Whereas, the other four treatments were kept in the last sector under chronic heat stress condition (HS) $\left(38^{\circ} \mathrm{C} \pm 1\right.$; 55-65 \% RH) for three successive days/week from 11.00 am until $15.00 \mathrm{pm}$. The first heat stress group was fed the basal diet (B) only without any supplementation and used as a negative control (NC). Whereas, in the other three treatments, one group was fed the basal diet 
supplemented with $250 \mathrm{mg}$ Spirulina $/ \mathrm{kg}$ diet (Spirulina obtained from The National Institute of Oceanography and Fisheries (NIOF); Egypt.) platensis (250S), or a basal diet supplemented with $125 \mathrm{mg} / \mathrm{kg}$ diet Spirulina (125S), and group of $75 \mathrm{mg}$ vitamin $\mathrm{E} / \mathrm{kg}$ diet $(75 \mathrm{E})$. Feed and water were supplied ad-libitum along the experimental period. Vaccination and medical program were done according to common veterinarian care practice. The photoperiod was 23 hours of light per day throughout the experimental period. The feed intake (FI), body weight, and mortality were examined.

\subsection{Sampling and measuring parameters:}

At 14 weeks of age, five birds from each treatment were randomly selected, slaughtered. Part of the blood was collected on anticoagulants and another part without anticoagulants. Whole blood samples were used for the determination of red blood cells (RBCs), white blood cells (WBC'S) counts; hemoglobin $(\mathrm{Hb})$ content and packed cell volume (PCV) according to Wintrobe (1967). Differential leukocytes count, blood film was prepared according to the method described by (Lucky, 1977). The percentage and absolute value for each type of cells were calculated according to (Schalm, 1986). The tubes that contain coagulated blood were kept at room temperature for an approximate half-hour to allow the clotting of blood after that the serum samples were separated by centrifugation $(3000 \mathrm{rpm} / 15$ min.) and stored $\left(-20^{\circ} \mathrm{C}\right)$. The analyzed parameters were total protein, albumin, Creatinine, ALT and AST by using commercial kits (from Biomerieux, Poains, France). Serum immunoglobulins (IgG, $\operatorname{IgM}$, and $\operatorname{Ig} \mathrm{A}$ ) were determined using commercial ELISA kits (Kamiya Biomedical Company, USA). Total antibody production specific for the NDV vaccine was determined in serum by means of an ELISA using commercial ELISA test kits (Jeffery et al., 1996). HI test was applied for the determination of an antibody response according to King and Seal (1998).

Liver and breast meat samples were carefully excised from the bird and immediately immersed in a saline solution $(0.9 \% \mathrm{NaCl})$. The liver and breast meat samples $(10 \%)$ were prepared in $0.01 \mathrm{M}$ Tris-HCl buffers ( $\mathrm{pH}$ 7.5). The homogenate was centrifuged at 4000 r.p.m for $15 \mathrm{~min}$, and the resultant supernatants were used for hepatic and meat parameters assay. Lipid peroxidation in liver and breast meat were estimated colorimetrically by measuring Malondialdehyde (MDA) by the thiobarbituric acid assay procedure using a kit purchased from Bio- Diagnostic, Egypt (CAT NO. MD 2529). Glutathione peroxidase (GPx) was determined using a kit purchased from Bio- Diagnostic, Egypt (CAT NO. GP 2524).

\section{Statistical analysis}

Data were statistically analyzed using one way ANOVA of SAS ${ }^{\circledR}$ (SAS Institute, 2001). Differences among treatment means were estimated by Duncan's multiple range test (Duncan, 1955). The following model was used to study the effect of treatments on the parameters investigated as follows:

$$
Y i j=\mu+T i+e i j .
$$

Where: $\mathrm{Yij}=$ an observation, $\mu=$ overall mean, $\mathrm{Ti}=$ effect of treatment $(\mathrm{i}=1,2,3, \ldots . .5)$ and eij $=$ experimental random error.

\section{Results and Discussion}

Spirulina is considered as a functional food due to its high protein content, high amount of vitamin and mineral content, carotene and xanthophyll phytopigments (Farag et al., 2016; Lupatini, et al., 2017), and it is generally regarded as safe (GRAS) by the European Food Safety Authority (EFSA) (Chacon-Lee et al., 2010). The results indicated that the final body weight (BW) and body weight gain (BWG) results 
were not significantly differed among different experimental groups at the end of experiment. Meanwhile, feed consumption (FI) is significantly decreased for the groups raised under heat stress (HS) compared with positive control group, while feed conversion ratio (FCR) was significantly improved for the groups supplied with both levels of Spirulina or vitamin E under HS compared with the group under HS and had no supplementation. However, the group supplemented with $125 \mathrm{mgSpirulina} / \mathrm{kg}$ diet recorded the significant best FCR compared with the PC, NC groups and the group supplemented with VE (Table 2). These results are compatible with the observation reported by Kirunda et al. (2001) that the reduction in feed intake is response to heat stress. In addition, the supplementation of basal diet with both levels of Spirulina or VE significantly improved the FCR for the groups reared under HS compared with the NC groups and statistically equal with the FCR for PC group. The improve on FCR in the present study is in agreement with that reported by Kaoud (2012) and Kharde et al. (2012) who found that feed conversion ratio improved by the dietary inclusion of the Spirulina platensis as compared to the control. Mariey et al.(2014) reported that supplied broiler with $0.1,0.2$ and $0.3 \mathrm{~g}$ Spirulina/kg diet improved feed conversion ratio by 5,10 and $12 \%$ as compared to those fed the control diet. Jamil et al. (2015) noted that FCR was significantly improved among the treatment groups of broiler chicks fed with Spirulina diet (0, 2, 4 and 8 g Spirulina $/ \mathrm{kg}$ ) for 4 weeks. Shanmugapriya et al. (2015) found that feed conversion ratio of broiler chicks was significantly increased by the dietary inclusion of the $1 \%$ of spirulina platinsis as compared to the control. Zeweil et al. (2016) reported that dietary supplementation of Spirulina in chickens under heat stress conditions could decrease adverse effects of chronic heat stress on growth performance of a Gimmizah chicken. Also, Levine et al. (2018) demonstrated that birds receiving dried algae at 50 and $200 \mathrm{~g} / \mathrm{ton}$ showed a significant improvement in broiler FCR compared to the control during HS period (days 14-20). The FCR improvement may be due to that Spirulina has some components which had beneficial effects improved the absorption of nutrients through the gastric tract. These findings are in harmony with those documented by Nikodémusz et al. (2010) who reported that broilers fed Spirulina-containing diets achieved superior productive performance to their control birds. Also, Gružauskas et al. (2004) reported that Spirulina improve absorption of minerals, protect from diarrhea and optimize nutrient digestion processes. Enass et al. (2019) indicated that supplementation of Spirulina platinsis had no adverse effect on body weight change and final body weight also, the best feed conversion had been recorded by birds fed Spirulina platinsis compared with control group.

Results of the blood parameters in Table (3) showed significant increase on the count of WBCs for the NC group (exposed to HS without any supplementation) compared with other groups, while the same group was significantly recorded the lowest values of $\mathrm{RBCs}$ and $\mathrm{Hb}$ compared with the other groups. However, the PCV value was statistically equal among all experimental groups. The differential of leukocytic count indicated that the $\mathrm{NC}$ group recorded significant increase on Lymphocyte, Heterophil and the ratio of $\mathrm{H} / \mathrm{L}$ compared with other groups, while the groups supplied with Spirulina or vitamin E significantly improved compared with the NC group and statistically equal with the PC group. The values of Monocyte and Basophil for the NC group were significantly decreased compared with the values recorded for the 
PC group, meanwhile the values for the other groups which supplied with Spirulina or vitamin $\mathrm{E}$ were significantly higher than $\mathrm{NC}$ group and statistically equal with the PC group. The value of Esinophil for the NC group was significantly decreased compared with the values recorded for the PC group; meanwhile the values for the other groups were flocculated. These results are an agreement with several reports (Seyidoglu and Galip, 2014; Mariey et al., 2014; Ashgan et al., 2015). Lokapirnasari et al. (2016) and Kumari et al (2019) noted that Spirulina improved the development and maturation of leukocytes, which is a pivotal part of the immune defense of broiler due to its content of phycocyanin and polysaccharides. Likewise, Jamil et al (2015) revealed that supplementation of Spirulina resulted in increased red blood cells count of chickens groups fed 0.1, 0.2 and $0.3 \mathrm{~g}$ Spirulina $/ \mathrm{kg}$ diet, also increased numbers of leukocytes and that associated with improved haemoglobin. In the same line, Zeweil et al. (2016) demonstrated that supplementations of Spirulina resulted in diminishing the negative effect of heat stress on WBCs, RBCs, lymphocyte and basophile. Moreover, Fathi et al. (2018) noticed a decrease on heterophils to lymphocyte $(\mathrm{H} / \mathrm{L})$ ratio, which is the indicator of stress condition of broiler chickens fed dietary inclusion of Spirulina platensis.

The results of the serum biochemistry showed that exposing to HS significantly decreased the concentration of total protein compared to the concentration of the PC group. While, the group exposing to $\mathrm{HS}$ (NC) significantly increased the concentration of blood albumin compared to the concentration of the PC group and statistically equal with the groups supplied with $125 \mathrm{mg}$ Spirulina $/ \mathrm{kg}$ diet and VE. Meanwhile, the group under HS and supplied with $250 \mathrm{mg}$ Spirulina/kg diet recorded the significantly lowest concentration and statistically equal with PC group. The NC group recorded the lowest globulin concentration compared with the other experimental groups and the PC group showed the opposite result. However, the concentration of globulin was significantly improved for the groups supplied with both levels of Spirolina (205 and $125 \mathrm{mg} / \mathrm{kg}$ diet) under HS compared with the NC group (Table 4). In this connection, Kutlu and Forbes (1993) reported that plasma total protein may give an indication of the effect of heat stress in chicken. Youssef $\boldsymbol{e t} \boldsymbol{a l}$. (2014) reported that plasma protein concentration decreased significantly after acute heat stress of Golden Montazah, Fayoumi and El- Salam during starter and growing periods (1-18 wk of age). Also, Tawfeek et al.(2014) indicated that the heat stress $\left(36{ }^{\circ} \mathrm{C}\right.$ and $\left.75 \% \mathrm{RH}\right)$ significantly decreased protein, compared with the thermoneutral control group $\left(25 \mathrm{C}^{\circ}\right.$ and $67 \% \mathrm{RH})$ for 6 weeks of broiler chicks. Mariey et al. (2014) found that broiler chicks for (0 to 6wk) fed dietary Spirulina supplementation at levels of 0.2 and $0.3 \mathrm{~g}$ $/ \mathrm{kg}$ diet significantly increased concentration of albumin and globulin in blood plasma compared with the control diet. Also, Mariey et al. (2012) showed that plasma total protein, albumin and globulin concentrations showed significant increase due to feeding dietary spirulina up to $0.2 \%$ of laying hens. Enass et al. (2019) recorded that Spirulina platinsis decreased only total protein and had insignificant effect on albumin compared with control group.

Creatinine, AST and ALT concentrations were significantly increased for the $\mathrm{NC}$ group compared with the other experimental groups. However, the concentrations of all of them were significantly improved due to supplementation of different levels of spirulina or VE and they statistically equals with PC group (Table 4). Regarding to 
ALT and AST activity, these results are in agreement with Jamil et al (2015) who reported that ALT and AST activity significantly decreased in all the treatment groups supplemented with Spirulina. Abdel-Daim et al. (2015) who reported that $500 \mathrm{mg}$ Spirulina $/ \mathrm{kg}$ of male Albino Wistar rats for 5 days results in significant decreases on creatinine compared with the unsupplied group. Selim et al. (2017) demonstrated that there was a significant decrease in ALT and AST concentrations in laying groups fed Spirulina platensis algae. The observed reduction in serum ALT and AST levels of Spirulina-supplemented groups in the current study revealed the hepatoprotective activity of the Spirulina platensis as a result of its antioxidant and anti-inflammatory factors. Also, Zeweil et al. (2019) results indicated that different supplementations as Spirulina 0.5 and 1 $\mathrm{g} / \mathrm{kg}$ diet $)$ and VE ( $75 \mathrm{mg} / \mathrm{kg}$ diet) decreased adverse effect of heat stress on createinin, ALT and AST of Chickens.

Blood Total antioxidant capacity (TAC) and Malondialdehyde (MDA) were not significantly differed among experimental groups, while liver MDA for group exposed to HS was significantly increased compared with the other experimental groups (Table 5). Glutathione peroxidase (GSH-PX) activity in blood and meat recorded the same trend, since the activity of GSH-PX for the NC group was significantly decreased compared with the other experimental groups. However, the activity of GSH-PX was significantly improved for the supplemented group with both levels of Spirulina platinsis or VE and almost equal with the activity which was recorded for PC group. In this context, these results are in agreement with Deng and Chow (2010) who indicate that Spirulina had an antioxidative and an antiinflammatory effect. El-Damrawy (2014) showed that Hubbard broiler chicks reared under heat stress $\left(36 \pm 1^{\circ} \mathrm{C}\right)$ and $65 \pm 5 \% \mathrm{RH}$ for $8 \mathrm{~h}$ (From 10 am to $6 \mathrm{pm}$ ) significantly decreased glutathione (GSH) activity compared to control group during $22 \mathrm{~d}$ to 40d of age. Also, Tawfeek et al. (2014) demonstrated that the heat stress $\left(36{ }^{\circ} \mathrm{C}\right.$ and $75 \% \quad \mathrm{RH}) \quad$ significantly decreased glutathione peroxidase, compared with the thermoneutral control group $\left(25 \mathrm{C}^{\circ}\right.$ and $67 \% \mathrm{RH})$ at 6 weeks of age in broiler chicks. It is worthnoting that, Spirulina contains numerous bioactive materials including phytopigments, such as phycobilins, phycocyanin, allophycocyanin and xanthophylls, which make it a potential natural dietary source of antioxidants, antiinflammatory, immune-modulating and hepatoprotective functions (Bermejo et al., 2008; Lokapirnasari et al., 2016; Ibrahim and Abdel-Daim, 2015; Abdel-Daim et al., 2015; Lu et al., 2006; Jamil et al., 2015 and Jeyaprakash and Chinnaswamy, 2005). Also, Kuhad et al. (2006) reported that Spirulina is well known to have antioxidant properties, which are attributed to its content of phycocyanin, beta-carotene and tocopherol bioactive molecules. It has been found that Spirulina is capable of inhibiting carcinogenesis and organspecific toxicity due to its antioxidant properties. Zeweil et al. (2016) demonstrated that malondialdehyde (MDA) concentration in liver was not significantly affected by Spirulina levels at 1 and $0.5 \mathrm{gm} / \mathrm{kg}$ diet and Vit.E supplementation under normal and heat stress conditions. Ashgan et al. (2015) showed that mice treated with Spirulina (800 mg SP/kg body weight/ $0.5 \mathrm{ml}$ drinking water) reduced MDA in comparison with Carbon tetrachloride $(\mathrm{CCl} 4,1 \mathrm{ml} / \mathrm{kg}$ body weight) as a toxin group for three weeks. Enass et al. (2019) demonstrated that Addition of Spirulina platinsis significantly decreased MDA compared to control group. Moreover, Spirulina contains notably 
phycocyanin that has the ability to scavenge free radicals, including alkoxyl, hydroxyl, and peroxyl radicals and $\beta$-carotene that have potent antioxidant and antiinflammatory activities. It also decreases nitrite production, suppresses inducible nitric oxide synthase (iNOS) expression, and inhibits liver microsomal lipid peroxidation (Romay et al., 1998 \& Riss et al., 2007). Zeweil et al. (2016) indicated that supplementation of Spirulina (0.5 and 1 $\mathrm{g} / \mathrm{kg}$ diet $)$ and $\mathrm{VE} \quad(75 \mathrm{mg} / \mathrm{kg}$ diet $)$ (decreased adverse effect of heat stress on immunity of chickens.

Immunoglobulin $\operatorname{IgA} \operatorname{IgM}$ and $\operatorname{IgM}$ for Gimmizah chicks at 14 wk of age were not significantly affected by dietary Spirulina levels or VE supplementation Table (6). These are in agreement with Enass et al. (2019) recorded that the highest significant TAC, GPx and IgG values were recorded with birds fed $0.15 \mathrm{~g}$ Spirulina platinsis $/ \mathrm{kg}$ diet compared with control group.

Haemagglutination inhabitation test of New Castle diseases virus (HIN) on 7 and 14 days post-vaccination, Avian influenza disease titer (HI A) were not significantly changed among different experimental groups. However, haemagglutination inhabitation test of Infections Bronchitis (HI IB) titers were significantly decreased due to exposing to $\mathrm{HC}$, since the lowest concentration was recorded for the $\mathrm{NC}$ group, while the other groups were significantly higher compared with the NC group. The highest result of HIB was recorded for the group supplied with VE and the concentration recorded for $\mathrm{t} P C$ group, (Table 6). In this respect, Mirzaie et al. (2018) reported that dietary supplementation of microalga was attributed to the higher antibody response against sheep red blood cells (SRBC) in broiler chickens. Habibian et al. (2014) noted that broiler chicks under HS $\left(23.9\right.$ to $37{ }^{\circ} \mathrm{C}$ cycling) at 49 days of age fed dietary VE had a significantly reduction on antibody titers for primary and secondary antibody responses too. Tang and Chen (2015) found that the titers of ND antibody in HS group exposed to $40 \pm 0.5^{\circ} \mathrm{C}$ for $2 \mathrm{~h}$ each day, were significantly lower than those in control group of male chicks at 42 days of age. Similarly, the study by Mirzaie et al (2018) documented a beneficial impact of feeding Spirulina on the second humoral response against SRBC antigen when compared with the control. Zeweil et al. (2016) stated that the highest significant effect on $\operatorname{IgG}$ in blood and glutathione peroxidase in liver and meat and the lowest significant malondialdehyde in meat values were recorded with the chicks fed $1 \mathrm{~g}$ Spirulina / kg diet under heat stress compared with the control (NC) group.

In conclusion, addition of Spirulina platensis improved growth performance, immunity and can be decreased adverse effect stress on Gimmizah chicks during growing period under heat stress condition. 
Table (1): Composition and calculated analysis of the basal experimental diet

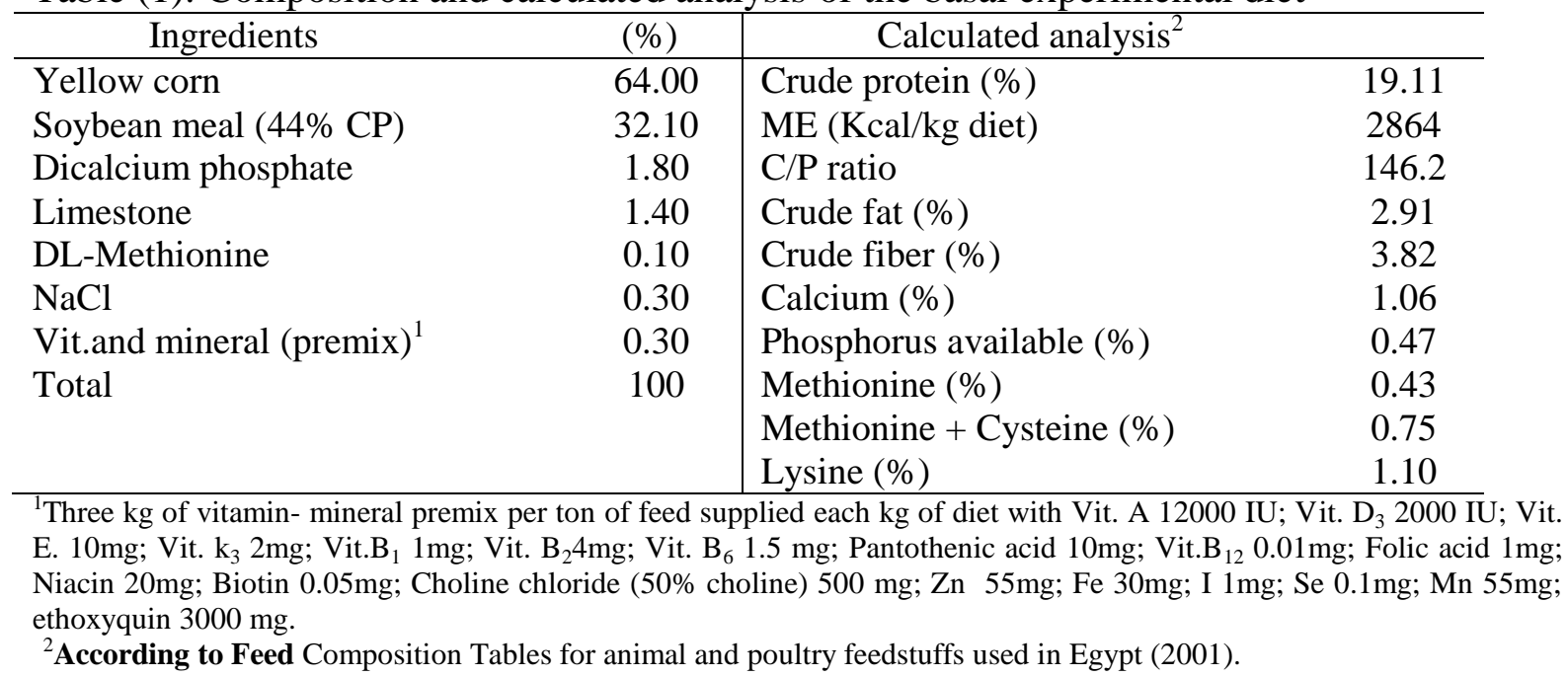

Table (2): Effect of Spirulina platensis supplementation and heat stress on Growth Performance of Gimmizah chicks

\begin{tabular}{|c|c|c|c|c|c|c|c|}
\hline $\begin{array}{l}\text { Groups } \\
\text { Parameters }\end{array}$ & $\begin{array}{c}\mathrm{T} 1 \\
(\mathrm{~B}, \mathrm{PC})\end{array}$ & $\begin{array}{c}\mathrm{T} 2 \\
(\mathrm{~B}, \\
\mathrm{NC})\end{array}$ & $\begin{array}{c}\mathrm{T} 3 \\
(\mathrm{~B}+250 \mathrm{~S})\end{array}$ & $\begin{array}{c}\mathrm{T} 4 \\
(\mathrm{~B}+125 \mathrm{~S})\end{array}$ & $\begin{array}{c}\mathrm{T} 5 \\
(\mathrm{~B}+75 \mathrm{E})\end{array}$ & \multirow[t]{2}{*}{ SEM } & \multirow[t]{2}{*}{ Sig } \\
\hline \multicolumn{6}{|c|}{ Under heat stress } & & \\
\hline IBW(g) & 366.6 & 373.6 & 383.9 & 379.6 & 381.1 & 32.22 & 0.2361 \\
\hline FBW $(\mathrm{g})$ & 1124.5 & 1049.6 & 1114.8 & 1221.4 & 1120.2 & 40.25 & 0.3251 \\
\hline BWG(g/day) & 10.82 & 9.66 & 10.44 & 12.03 & 10.56 & 1.06 & 0.0852 \\
\hline $\mathrm{FI}(\mathrm{g} /$ day $)$ & $52.19^{\mathrm{a}}$ & $50.23^{\mathrm{b}}$ & $46.22^{\mathrm{b}}$ & $48.79^{\mathrm{b}}$ & $50.29^{\mathrm{b}}$ & 1.45 & 0.0034 \\
\hline $\begin{array}{l}\text { FCR } \\
\text { (gFI/gBWG) }\end{array}$ & $4.82^{b}$ & $5.20^{\mathrm{a}}$ & $4.43^{\mathrm{bc}}$ & $4.06^{c}$ & $4.76^{b}$ & 0.48 & 0.0007 \\
\hline
\end{tabular}

T1 (B, PC): fed Basal diet (positive control). T2 (B, NC):fed Basal diet under HS (negative control). T3 (B+250S): fed B + 250 mg Spirulina / Kg under HS. T4(B+125S): fed B + 125 mg Spirulina / Kg under HS. T5 (B+75E): fed B + 75 mg V

E/ Kg under HS. IBW: Initial body weight FBW: Final body weight FI: Feed intake, FCR:Feed conversion ratio 
Table (3): Effect of Spirulina platensis supplementation and heat stress on some blood parameters of Gimmizah chicks

\begin{tabular}{|c|c|c|c|c|c|c|c|}
\hline Groups & $\begin{array}{c}\mathrm{T} 1 \\
(\mathrm{~B}, \mathrm{PC})\end{array}$ & $\begin{array}{c}\mathrm{T} 2 \\
(\mathrm{~B}, \mathrm{NC}) \\
\end{array}$ & $\begin{array}{c}\mathrm{T} 3 \\
(\mathrm{~B}+250 \mathrm{~S})\end{array}$ & $\begin{array}{c}\mathrm{T} 4 \\
(\mathrm{~B}+125 \mathrm{~S}) \\
\end{array}$ & $\begin{array}{c}\text { T5 } \\
(\mathrm{B}+75 \mathrm{E})\end{array}$ & SEM & Sig \\
\hline Parameters & \multicolumn{7}{|c|}{ Under heat stress } \\
\hline WBCs & $24.00^{b}$ & $27.67^{\mathrm{a}}$ & $23.67^{\mathrm{b}}$ & $24.0^{\mathrm{b}}$ & $24.67^{b}$ & 0.994 & 0.0042 \\
\hline RBCs $/ 10$ & $13.66^{\mathrm{a}}$ & $11.33^{\mathrm{b}}$ & $13.33^{\mathrm{a}}$ & $13.66^{\mathrm{a}}$ & $13.0^{\mathrm{a}}$ & 0.962 & 0.0005 \\
\hline $\mathrm{PCV}$ & 33.67 & 32.0 & 33.33 & 33.66 & 33.0 & 1.392 & 0.3521 \\
\hline $\mathrm{Hb}$ & $12.33^{\mathrm{b}}$ & $10.0^{\mathrm{c}}$ & $16.33^{\mathrm{a}}$ & $11.33^{\mathrm{b}}$ & $11.67^{\mathrm{b}}$ & 0.822 & 0.0045 \\
\hline \multicolumn{8}{|c|}{ Differential leukocytic count } \\
\hline Lymphocyte & $42.33^{\mathrm{b}}$ & $42.24^{\mathrm{a}}$ & $43.49^{\mathrm{b}}$ & $42.40^{\mathrm{b}}$ & $44.33^{\mathrm{b}}$ & 0.736 & 0.0056 \\
\hline Monocyte & $15.23^{\mathrm{a}}$ & $10.44^{\mathrm{b}}$ & $14.32^{\mathrm{a}}$ & $13.91^{\mathrm{a}}$ & $12.71^{\mathrm{ab}}$ & 0.550 & 0.0023 \\
\hline Basophil & $1.65^{\mathrm{a}}$ & $0.33^{\mathrm{b}}$ & $1.71^{\mathrm{a}}$ & $1.72^{\mathrm{a}}$ & $1.47^{\mathrm{a}}$ & 0.268 & 0.0012 \\
\hline Eosinophil & $16.38^{\mathrm{a}}$ & $12.10^{\mathrm{bc}}$ & $12.00^{\mathrm{bc}}$ & $14.0^{\mathrm{ab}}$ & $10.73^{\mathrm{c}}$ & 0.690 & 0.0003 \\
\hline Heterophil & $24.69^{c}$ & $33.24^{\mathrm{a}}$ & $28.0^{\mathrm{b}}$ & $27.83^{\mathrm{b}}$ & $29.01^{\mathrm{b}}$ & 0.556 & 0.0001 \\
\hline $\mathrm{H} / \mathrm{L}$ ratio & $0.58^{\mathrm{c}}$ & $0.78^{\mathrm{a}}$ & $0.65^{\mathrm{b}}$ & $0.65^{\mathrm{b}}$ & $0.65^{\mathrm{b}}$ & 1.608 & 0.0001 \\
\hline
\end{tabular}

T1 (B, PC): fed Basal diet (positive control). T2 (B, NC):fed Basal diet under HS (negative control). T3 (B+250S): fed B + 250 mg Spirulina / Kg under HS. T4(B+125S): fed B + 125 mg Spirulina / Kg under HS. T5 (B+75E): fed B + 75 mg V E/ Kg under HS.. H/L= Heterophil/ Lymphocyte ratio

Table (4): Effect of Spirulina platensis supplementation and heat stress on some serum biochemistry parameters of Gimmizah chicks

\begin{tabular}{|c|c|c|c|c|c|c|c|}
\hline \multirow{2}{*}{ Parameters } & $\begin{array}{c}\mathrm{T} 1 \\
(\mathrm{~B}, \mathrm{PC})\end{array}$ & $\begin{array}{c}\mathrm{T} 2 \\
(\mathrm{~B}, \mathrm{NC})\end{array}$ & $\begin{array}{c}\mathrm{T} 3 \\
(\mathrm{~B}+250 \mathrm{~S})\end{array}$ & $\begin{array}{c}\mathrm{T} 4 \\
(\mathrm{~B}+125 \mathrm{~S})\end{array}$ & $\begin{array}{c}\text { T5 } \\
(B+75 E)\end{array}$ & \multirow[t]{2}{*}{ SEM } & \multirow[t]{2}{*}{ Sig } \\
\hline & \multicolumn{5}{|c|}{ Under heat stress } & & \\
\hline Total protein $(\mathrm{g} / \mathrm{dl})$ & $7.53^{\mathrm{a}}$ & $6.20^{\mathrm{b}}$ & $6.70^{b}$ & $6.75^{b}$ & $6.42^{b}$ & 0.407 & 0.0001 \\
\hline Albumin $(\mathrm{g} / \mathrm{dl})$ & $3.23^{\mathrm{c}}$ & $3.74^{\mathrm{a}}$ & $3.16^{\mathrm{c}}$ & $3.66^{\mathrm{ab}}$ & $3.31^{\mathrm{ab}}$ & 0.092 & 0.0024 \\
\hline Globulin $(\mathrm{g} / \mathrm{dl})$ & $4.29^{\mathrm{a}}$ & $2.46^{\mathrm{c}}$ & $3.54^{\mathrm{b}}$ & $3.09^{\mathrm{b}}$ & $3.12^{b}$ & 0.476 & 0.0054 \\
\hline Creatinine $(\mathrm{mg} / \mathrm{dl})$ & $0.57^{\mathrm{b}}$ & $0.76^{\mathrm{a}}$ & $0.58^{\mathrm{b}}$ & $0.63^{\mathrm{ab}}$ & $0.57^{\mathrm{b}}$ & 0.050 & 0.0006 \\
\hline AST $(\mathrm{U} / \mathrm{L})$ & $57.01^{\mathrm{b}}$ & $65.33^{\mathrm{a}}$ & $56.93^{\mathrm{b}}$ & $58.87^{\mathrm{b}}$ & $57.33^{\mathrm{b}}$ & 0.746 & 0.0384 \\
\hline $\operatorname{ALT}(\mathrm{U} / \mathrm{L})$ & $32.80^{\mathrm{b}}$ & $35.67^{\mathrm{a}}$ & $32.67^{\mathrm{b}}$ & $33.5^{\mathrm{b}}$ & $31.67^{\mathrm{b}}$ & 1.576 & 0.0241 \\
\hline
\end{tabular}

T1 (B, PC): fed Basal diet (positive control). T2 (B, NC):fed Basal diet under HS (negative control). T3 (B+250S): fed B + 250 mg Spirulina / Kg under HS. T4(B+125S): fed B + $125 \mathrm{mg}$ Spirulina / Kg under HS. T5 (B+75E): fed B + 75 mg V E/ Kg under HS. 
Table (5): Effect of Spirulina platensis supplementation and heat stress on some antioxidant parameters

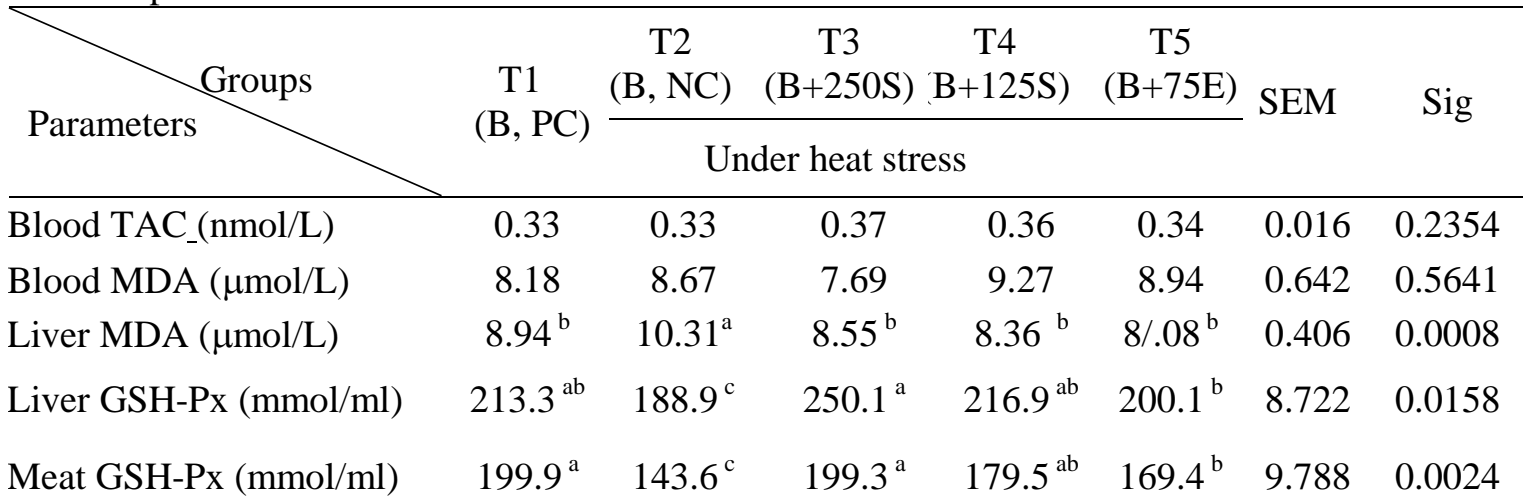

T1 (B, PC): fed Basal diet (positive control). T2 (B, NC):fed Basal diet under HS (negative control). T3 (B+250S): fed B + 250 mg Spirulina / Kg under HS. T4(B+125S): fed B + 125 mg Spirulina / Kg under HS. T5 (B+75E): fed B + 75 mg V E/ Kg under HS. TAC: Total antioxidant. MDA: Malondialdehyde. GSH-Px: Glutathione peroxidase

Table (6): Effect of Spirulina platensis supplementation and heat stress on some immune parameters

\begin{tabular}{|c|c|c|c|c|c|c|c|}
\hline \multirow{2}{*}{ Groups } & $\begin{array}{c}\mathrm{T} 1 \\
(\mathrm{~B}, \mathrm{PC})\end{array}$ & $\begin{array}{c}\mathrm{T} 2 \\
(\mathrm{~B}, \mathrm{NC})\end{array}$ & $\begin{array}{c}\mathrm{T} 3 \\
(\mathrm{~B}+250 \mathrm{~S})\end{array}$ & $\begin{array}{c}\mathrm{T} 4 \\
(\mathrm{~B}+125 \mathrm{~S})\end{array}$ & $\begin{array}{c}\mathrm{T} 5 \\
(\mathrm{~B}+75 \mathrm{E})\end{array}$ & \multirow[t]{2}{*}{ SEM } & \multirow[t]{2}{*}{ Sig } \\
\hline & \multicolumn{5}{|c|}{ Under heat stress } & & \\
\hline $\operatorname{IgA}$ & 77.00 & 78.66 & 79.00 & 78.33 & 77.00 & 0.822 & 0.0725 \\
\hline $\operatorname{IgM}$ & 220.33 & 225.33 & 221.67 & 222.00 & 220.33 & 2.058 & 0.0684 \\
\hline $\operatorname{IgG}$ & $967.67^{b}$ & $973.66^{\mathrm{ab}}$ & $977.00^{\mathrm{a}}$ & $970.66^{a b}$ & $967.67^{b}$ & 1.776 & 0.0002 \\
\hline HI IB & $2.00^{\mathrm{a}}$ & $1.00^{\mathrm{c}}$ & $1.67^{\mathrm{b}}$ & $1.65^{b}$ & $2.00^{\mathrm{a}}$ & 0.140 & 0.0025 \\
\hline HI A & 1.00 & 1.33 & 0.67 & 1.00 & 1.00 & 0.202 & 0.4521 \\
\hline HI N7 & 2.33 & 3.33 & 3.00 & 3.33 & 2.33 & 1.026 & 0.2314 \\
\hline HI N14 & 3.33 & 4.00 & 3.66 & 4.00 & 3.33 & 0.398 & 0.2541 \\
\hline
\end{tabular}

T1 (B, PC): fed Basal diet (positive control). T2 (B, NC):fed Basal diet under HS (negative control). T3 (B+250S): fed B + 250 mg Spirulina / Kg under HS. T4(B+125S): fed B + 125 mg Spirulina / Kg under HS. T5 (B+75E): fed B + 75 mg V E/ $\mathrm{Kg}$ under HS. HI N= Haemagglutination inhabitation test of New Castle diseases virus (NDV). HI IB = Haemagglutination inhabitation test of Infections Bronchitis (IB).HI A= Haemagglutination inhabitation test of Avian influenza disease (H5N1). HI N7 = Haemagglutination inhabitation test of (NDV) on 7 day. HI N14 = Haemagglutination inhabitation test of (NDV) on 14 day. 


\section{References}

Abdel-Daim, M.M.; Farouk, S.M.; Madkoup, F.F. \& Azab, S.S. (2015). Antiinflammatory and immunomodulatory effects of Spirulina platensis in comparison to Dunaliella Salina in acetic acidinduced rat experimental colitis. Immunopharm. Immunot. 37, 126139.

Anbarasan, V.; Kumar, V. K.; Kumar, P. S. \& Venkatachalam, T. (2011). In vitro evaluation of antioxidant activity of blue green algae Spirulinaplatensis. Volume,2(10):2616-2618.

Ashgan A. AbouGabal; Haiam M. Aboul-Ela; Eman M Ali; Ahemd E.M k. \& Ola Kh. Shalaby. (2015). Hepatoprotective, DNA Damage Prevention and Antioxidant Potential of Spirulina platensis on CCl4- Induced Hepatotoxicity in Mice. American Journal of Biomedical Research 2, 29-34.

Attia, Y.A.; Böhmer Barbara M. \& Roth-Maier, D.A. (2006). Responses of broiler chicks raised under constant relatively high ambient temperature to enzymes, amino acid supplementations, or diet density. Archiv Für Geflügelkunde., 70: 8091.

Batista, A.P.; Gouveia, L.; Bandarra, N.M.; Franco, J.M. \& Raymundo, A. (2013). Comparison of microalgal biomass profiles as novel functional ingredient for food products. Algal Res. 2, 164-173.

Bermejo-Bescós, P.; Piñero-Estrada E. \& Villar Del Fresno, A. M. (2008). Neuroprotection by Spirulina platensis protein extract and phycocyanin against iron-induced toxicity in SH-SY5Y neuroblastoma cells. Toxicol. In Vitro, 22:14951502.

Bollengier-Lee, S.; Williams P.E. \& Whitehead C.C. (1999). Optimal dietary concentration of vitamin $\mathrm{E}$ for alleviating the effect of heat stress on egg production in laying hens. Br. Poult. Sci., 40: 102-107.

Borwttzka, M.A. (2013) High-value products from microalgae-their development and commercialisation. J. Applied Phycol. 25, 743-75.

Chacon-Lee, T. \& Gonzàlez-Marino, G. (2010). Microalgae for "healthy" foodsPossibilities and challenges. Compr. Rev. Food Sci. Food Saf., 9, 655675.

Christaki, E.; Bonos, E.; Giannenas, I. \& FlorouPaneri, P. (2013). Functional properties of carotenoids originating from algae. J. Sci. Food Agric. 93, 5-11.

Daghir, N.J. (2008). Poultry Production in Hot Climates, 2nd Edition, Published by $\mathrm{CAB}$ International, Wallinford, Oxfordshire, UK, pp. 387.

Deng, R. \& Chow, T.J. (2010). Hypolipidemic, antioxidant, and antiinflammatory activities of microalgae Spirulina. Cardiovsac. Ther., 28, 33-45.

Duncan, D. B. (1955). Multiple range and F. Test-Biometrics, 11:1- 42.

El-Damrawy, S. Z. (2014). Effect of grape seed extract on some physiological changes in broilers under heat stress. Egypt. Poult. Sci. 34: 333-343.

Enass, Abd El-khalek; Abaza, I. M. \& Asmaa, A. Saad. (2019). Effect of dietary supplementation of Spirolina Platensis and organic selenium on some biological traits of local laying hen under heat stress conditions. Egypt. Poult. Sci., 39: 207-217.

Eriksen, N.T. (2008). Production of phycocyanin - a pigment with applications in biology, biotechnology, foods and medicine. Appl. Microbiol. Biotechnol. 80, 1-14.

Farag, M.R.; Alagawany, M.; Abd El-Hack, M.E.\& Dhama, K. (2016). Nutritional and healthical aspects of Spirulina (Arthrospira) for poultry, animals and human. Int. J. Pharm., $12,36-51$.

Fathi, M. A.; Namra, M. M. M; Ragab, M. S. \& Aly, M. M. M. (2018). Effect of dietary supplementation of algae 
meal (Spirulina platensis) as growth promoter on performance of broiler chickens. Egyptian Poultry Science, 38, 375-389.

Feed Composition Tables for Animal and Poultry Feedstuffs Used in Egypt (2001). Technical Bulletin. No.1, Central Lab for Feed and Food ; Ministry of Agriculture, Egypt.

Gružauskas, R.; Lekavicius, R.; RaceviciutStupelien, R.; Šašyt, V.T.\& Švirmickas, G.J. (2004). Višiuk broileriu virškinimo procesu optimizavimas simbiotiniais preparatais. Veterinarija ir Zootechnika, 28: 51-56.

Habibian, M.; Shahab, G.; Mohammad M. M. \& Alireza, A. (2014). Effects of dietary selenium and vitamin $\mathrm{E}$ on immune response and biological blood parameters of broilers reared under thermoneutral or heat stress conditions. Inter. Journal of Biometeorology. 58: 741-752.

Hamed, M.; Soliman, H.A.M. \& Sayed, A.E.H. (2019). Ameliorative effect of Spirulina platensis against lead nitrate-induced cytotoxicity and genotoxicity in catfish Clarias gariepinus. Environ. Sci. Pollut. Res. Int. 26, 20610-20618. [CrossRef].

Hemalatha, K., Pugazhendy, K.; Jayachandran, K.; Jayanthi, C. \& Meenambal, M. (2012). Studies on the Protective Efficacy of Spirulina against Lead Acetate Induced Hepatotoxicity in Rattusnorvegicus. International Journal of Chemical and Analytical Science 3: 1509-1512.

Hossain, F. M. A.; Hossain, M. M.;. Kabir, M. G. \& Fasina, F. O. (2013). Effectiveness of combined treatment using Spirulina and vitamin A against chronic arsenicosis in rats. Afr. J. Pharm. Pharmacol.7: 1260 1266.

Ibrahim, A.E. \& ABDEL-Daim, M.M. (2015). Modulating effects of Spirulina platensis against tilmicosin-induced cardiotoxicity in mice. Cell J. 17, 137-144.

Jamil, A. B. M. R.; Akanda, R.; Rahman, M.; Hossain, A. \& Islam, S. (2015). Prebiotic competence of spirulina on the production performance of broiler chickens. Journal of Advanced Veterinary and Animal Research, 2, 304309. http://dx.doi.org/10.5455/javar. 2015.b94

Jeffery, N.M.; Sanderson, P.; Sherrrington, E.J.; Newsholme, E.A. \& Calder. P.C. (1996). The ratio of $n-6$ to $n-3$ polyunsaturated fatty acids in the rat diet alters serum lipid levels and lymphocyte functions. Lipids, 31:737-745.

Jeyarakash, K. \& Chinaswamy, P. (2005). Effect of Spirulina and Liv-52 on cadmium induced toxicity in albino rats. Indian. J. Exp. Biol. 43, 773-781.

Kaoud, H. A. (2012). Effect of Spirulina platensis as a dietary supplement on broiler performance in comparison with prebiotics. Scientific Journal of Applied Research, 1, 44-48.

Kharde, S.D.; Shirbhate, R.N.; Bahiram, K.B. \& Nipane, S.F. (2012). Effect of spirulina supplementation on growth performance of broilers. Indian $\mathrm{J}$. Vet. Res. 21, 66-69.

King D.J. \& Seal, B. (1998). Biological and molecular characterization of Newcastle disease virus (NDV) field isolates with comparisons to reference NDV strains and pathogenicity after chicken or embryo passage of selected isolates. Avian Diseases.42:507-516.

Kirunda, D.F.K.; Scheideler, S. E. \& Mckee, S.R. (2001). The efficacy of vitamin E (DL- $\alpha$-tocophyryl acetat) supplementation in hen diets to alleviate egg quality seterioration associated with high temperature exposure. Poult. Sci., 80:1378-1383.

Kuhad, A.; Tirkey, N.; Pilkhwal, S. \& Chopra, K. (2006). Renoprotective effect of Spirulina fusiformis on cisplatininduced oxidative stress and renal 
dysfunction in rats. Ren. Fail., 28: 247-254.

Kumari, P.; Nehra, V.; Lather, D.; Kundu, P. \& Narang, G. (2019). Effect of Spirulina on growth and bursal index of infectious bursal disease vaccinated chickens. Haryana Veterinarian, 58, 70-72.

Kutlu, H. R. \& Forbes, J. M. (1993). Changes in growth and blood parameters in heat stressed broiler chicks in response to dietary ascorbic acid. Livestock Prod. Sci. 36: 335-350.

Levine, R.; Horst, G.; Tonda, R.; Lumpkins, B. \& Mathis, G. (2018). Evaluation of the effects of feeding dried algae containing beta-1,3-glucan on broilers challenged with Eimeria. Poultry Science 97:3494-3500. http://dx.doi.org/10.3382/ps/pey227.

Lokapirnasari, W. P.; Yulianto, A. B.; Legowo, D. \& Agustono, (2016). The effect of Spirulina as feed additive to myocardial necrosis and leukocyte of chicken with avian influenza (H5N1) virus infection. Procedia Chemistry, 18, 213217. https://doi.org/10.1016/j.proche .2016 .01 .033

Lucky, Z. (1977). Methods for the diagnosis of fish diseases. Ameruno Publishing Co, PVT, Ltd. New Delhi, Bomby, New York.

Lu, H.K.; Hsieh, C.C.; Hsu, J.J.; Yang Y.K. \& Chou, H.N. (2006). Preventive effects of Spirulina platensis on skeletal muscle damage under exercise-induced oxidative stress. Eur. J. Applied Physiol., 98: 220226.

Lupatini, A.L.; Colla, L.M.; Canan, C.; Colla, E. (2017). Potential application of microalga Spirulina platensis as a protein source. J. Sci. Food Agric., 97, 724-732.

Mahmoud, T.H.; Sayed, I.F.; Madkour, Y.H. \& Honein, M.M. (1982). The "Gimmizah" a new breed of chickens. Agric.Res.Rev.,60:51-67.

Maoka, T. (2011). Carotenoids in marine animals. Mar. Drugs 9, 278-293.
Mariey, Y.; Samak, A.H.R. \& Ibrahem, M.A. (2012). Effect of using spirulina platensis algae as a feed additive for poultry diets: Productive and reproductive performances of local laying hens. Egypt. Poult. Sci., 32, 201-215.

Mariey, Y. A.; Samak, H.R. \& Ibrahem, M.A. (2014). Effect of using spirulina platensis algae as afeed additive for poultry diets: 1- Productive and reproductive performances of local laying hens. Egypt. Poult. Sci. 32: 201-215.

Mashaly, M.M.; Hendricks, G.L.; Kalama, M.A.; Gehad, A.E.; Abbas, A.O. \& Patterson,v P.H. (2004). Effect of heat stress on production parameters and immune responses of commercial laying hens. Poult. Sci., 83: 889-894.

Mirzaie, S.; Fahim, Z.; Seyed, A. h. \& Hamid, D. (2018). Effects of dietary Spirulina on antioxidant status, lipid profile, immune response and performance characteristics of broiler chickens reared under high ambient temperature. AsianAustralas J Anim Sci 31:556-563.

Nikodémusz, E.; Páskai, P.; Tóth, L.and Kozák, J. (2010). Effect of dietary Spirulina supplementation on the reproductive performance of farmed pheasants. Technical Articles -Poultry Industry, pp. 1-2

Riss, J., Décordé, K.; Sutra, T.; Delage, M.; Baccou, J.C.; Jouy, N.; Brune, J.P.; Oréal, H.; Cristol, J. P. \& Rouanet, J. M. (2007). Phycobiliprotein Cphycocyanin from Spirulina platensis is powerfully responsible for reducing oxidative stress and NADPH oxidase expression induced by an atherogenic diet in hamsters. J.Agric Food Chem, 55:7962-7967.

Romay, C.; Armesto, J.; Remirez, D.; Gonz'alez, R.; Ledon, N.\& Garc'1a, I. (1998) Antioxidant and antiinflammatory properties of Cphycocyanin from blue-green algae. Inflamm Res, 47: 36-41. 
SAS (2001). SAS User's Guide Statistic. SAS Version 8.2. Inc. Cary. NC. USA.

Schalm, O.W. (1986). Veterinary hematology. 4th Ed., Lea and Febiger, Philadelphia.

Seyidoğlu, Nilay \& Galip, Nurten. (2014) Effects of Saccharomyces cerevisiae and Spirulina platensis on growth performances and biochemical parameters in rabbits. Kafkas Univ Vet Fak Derg 20(3): 331-336.

Shanmugapriya, B.; Saravana B.S.; Hariharan, T.; Sivaneswaran, S. \& Anusha, M.B. (2015). Dietary aministration of Spirulina platensis as probiotics on growth performance and histopathology in broiler chicks. International Journal of Recent Scientific Research Vol. 6, Issue, 2, pp.2650-2653.

Tang, J. \& Chen, Z. (2015). The protective effect of $\gamma$-aminobutyric acid on the development of immune function in chickens under heat stress. Journal of Animal Physiology and Animal Nutrition 10:1111/jpn. 12385.

Tawfeek, S. S.; Hassanin, K. M. A. \& Youssef, I. M. I. (2014). The effect of dietary supplementation of some antioxidants on performance, oxidative stress, and blood parameters in broilers under natural summer conditions. J. World's Poult. Res. 4: 10-19.

Tumová E. \& Gous, R.M. (2012). Interaction of hen production type, age, and temperature on laying pattern and egg quality. Poult. Sci., 91: 12691275.

Wintrobe, M.M.. (1967). Clinical Hematology. 6th Edition PP., 414-419, Lea Febiger, hilade-lphia, S.A.

Yoshida, N.; Fujita, M.; Nakahara, M.; Kuwahara, T.; Kawakami, S.I. \& Bungo, T. (2011). Effect of high environmental temperature on egg production, serum lipoproteins and follicle steroid hormones in laying hens. J. Poult. Sci., 48: 207-211.

Youssef, S. F.; Doaa, M. M. Yassein; Nadia M. El-Bahy \& Faddle, A. A. (2014). A comparative studies among Golden Montazah, El- Salam and Fayoumi chickens.1- Response to acute heat stress as early heat conditioning procedure. Egypt. Poult. Sci. 34: 1075-1097.

Zeweil, H.; Abaza, I.M.; Zahran, S.M.; Ahmed, M. H., Haiam M. Aboul-Ela \& Asmaa, A. S. (2016). Effect of Spirulina platensis as dietary supplement on some biological traits for chickens under heat stress condition. Asian J. Biomed. Pharm. Sci. 6, 8-12. 


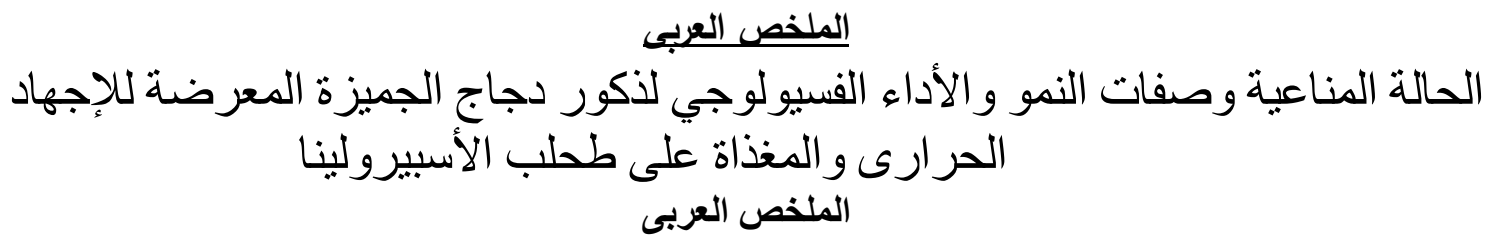

أجريت هذه التجربة لدر اسة تأثير طحلب الأسبيروليناعلى صفات النمو و كذلك الأداء الفسيولوجي لذكور دجاج الجميزة

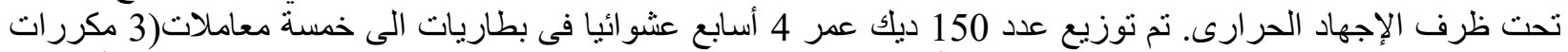

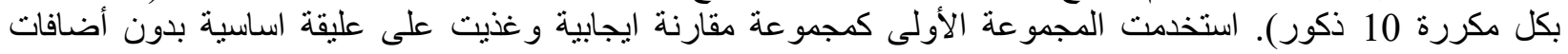
وربيت تحت الظروف الطبيعية (درجة الحرارة 22-24 مئوية ورطوبة نسبية 45-55\%). تم تربية المجموعات التجريبية الأربعة الأخرى فى غرفة تحت التحكم فى ظرف بلى بيئية مختلفة حيث تم رفع درجة الحر ارة بها الى درجة

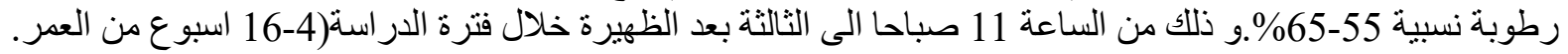

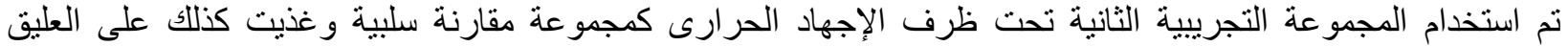

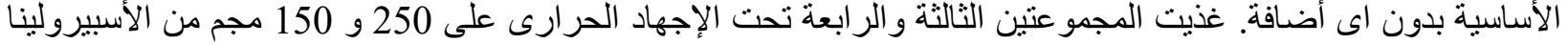

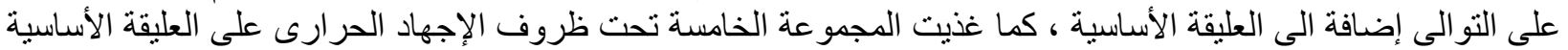

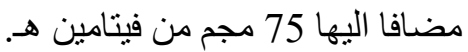

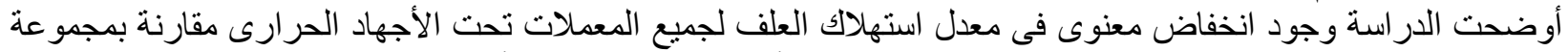

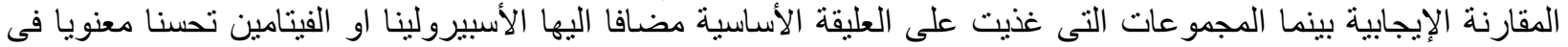

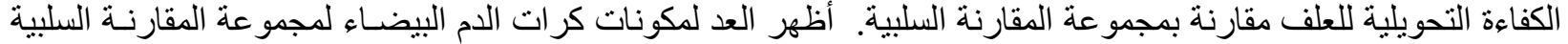

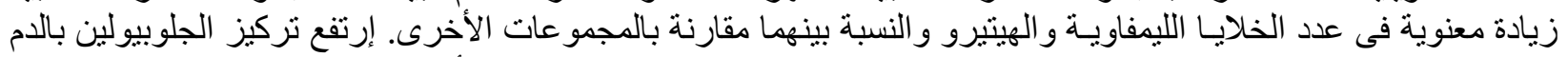

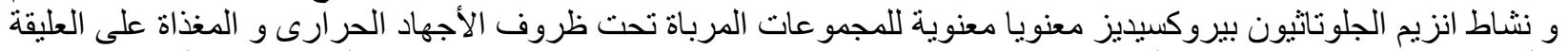

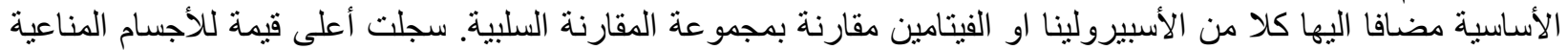

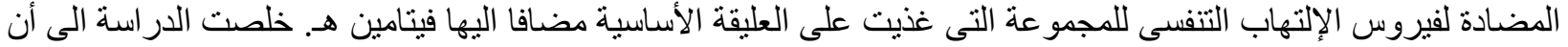

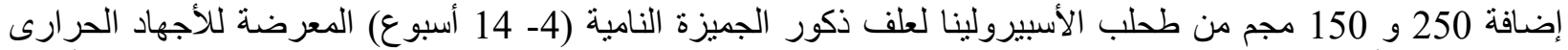

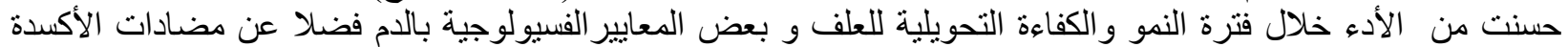

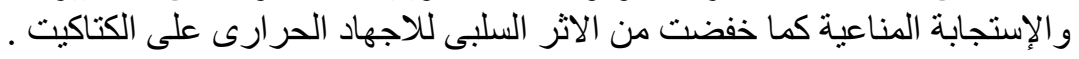

